\title{
FEEDING AND DECORATION PREFERENCES OF THE EPIALTIDAE CRAB ACANTHONYX SCUTIFORMIS
}

\author{
Marcelo Augusto Vasconcelos, Thiago Costa Mendes, Wagner Luiz Soares Fortes and Renato Crespo Pereira*
}

Universidade Federal Fluminense - Departamento de Biologia Marinha

(Caixa Postal 100.644, 24001-970 Niterói, RJ, Brasil)

*Corresponding author: renato.pereira@pq.cnpq.br

\section{A B S T R A C T}

Studies on the feeding preferences of marine herbivores are very important for our better understanding of the biology and the ecological role of these organisms. Members of the family Epialtidae are usually herbivores that mask themselves with pieces of seaweed and other materials to avoid predation. In order to better understand the mechanisms of food and decorating choices of the decorator crab Acanthonyx scutiformis, two multiple-choice feeding assays were performed using fresh seaweeds and artificial food containing crude extracts of the four seaweeds Osmundaria obtusiloba, Plocamium brasiliense, Sargassum sp., and Dictyota menstrualis, offered simultaneously to this crab species. In both assays the seaweed most consumed was $O$. obtusiloba, followed by $P$. brasiliense and Sargassum sp., while D. menstrualis was the least consumed. It is suggested that $A$. scutiformis is a generalist feeder, but with some preference for the perennial red seaweed $O$. obtusiloba and the chemically-defended seaweed P. brasiliense. Decorating behavior observations revealed the preferences of $A$. scutiformis by $P$. brasiliense. This decorating behavior can be interpreted as a mechanism to avoid generalist predators, since feeding and decorating preference were not associated and the crab used only small pieces of chemically defended algae.

\section{RESUMO}

Estudos sobre preferência alimentar de herbívoros marinhos são muito importantes para o melhor entendimento da importância biológica e ecológica destes organismos. Caranguejos majídeos são usualmente herbívoros que se camuflam com pedaços de macroalgas e outros materiais para evitar a predação. Para entender melhor os mecanismos de escolha de alimento e decoração do caranguejo decorador Acanthonyx scutiformis, foram realizados dois ensaios de múltipla escolha usando macroalgas frescas e alimentos artificiais contendo extratos brutos das macroalgas Osmundaria obtusiloba, Plocamium brasiliense, Sargassum sp. e Dictyota menstrualis, oferecidas simultaneamente a esta espécie de caranguejo. Em ambos ensaios, a macroalga mais consumida foi $O$. obtusiloba, seguida por $P$. brasiliense e Sargassum sp., enquanto $D$. menstrualis foi menos consumida. É sugerido que A. scutiformis é um consumidor generalista, mas com alguma preferência pela macroalga vermelha perenial $O$. obtusiloba e a macroalga quimicamente defendida $P$. brasiliense. Observações sobre o comportamento decorador revelaram a preferência de A. scutiformis por $P$. brasiliense. Este comportamento decorador pode ser interpretado como um mecanismo para evitar predadores generalistas, uma vez que as preferências por consumo e decoração não foram relacionadas e o caranguejo usou somente pequenos pedaços de algas quimicamente defendidas.

Descriptors: Acanthonix scutiformis, Feeding preference, Decoration preference.

Descritores: Acanthonyx scutiformis, Preferência alimentar, Preferência por decoração.

\section{INTRODUCTION}

Feeding preferences have been evaluated in several groups of marine herbivores, including mollusks (MCSHANE et al., 1994), crustaceans (DUFFY; HAY, 1991; BARRY; EHRET, 1993; STACHOWICZ; HAY 1999), sea urchins (VADAS 1977) and fishes (BARRY; EHRET 1993). However, the factors driving food choices are not yet clearly understood. Many hypotheses have been formulated to explain why some seaweeds in a community are consumed while others are avoided (GRANADO; CABALLERO, 2001).
For example, the nutritional value and abundance of a certain food item are factors that determine its consumption (NEIGHBORS; HORN 1991). However, it is important to note that some abundant and highly nutritional seaweeds may not be consumed by some herbivores in spite of being conspicuous items in the community. These observations have been attributed to the occurrence of chemical defenses, which are well documented in the marine environment (HAY, 1996; PAUL et al., 2001; PAUL; PUGLISI, 2004; PAUL et al., 2006). Feeding preference is thus not based solely on the herbivore's nutritional needs. 
Some seaweeds that provide food can also provide refuge for small and not highly mobile herbivores. Seaweeds possessing thalli of complex structure can act more effectively as shelter for these organisms as compared to others of simpler structure. In addition, the presence in structurally complex seaweeds of secondary metabolites that act as feeding deterrents against generalist consumers provides an additional protection for small herbivores (HAY, 1992). Their feeding preference may, thus, be directly correlated with the protection against omnivores provided by defended seaweeds. For instance, the amphipod Ampithoe longimana lives and feeds preferentially on the brown seaweed Dictyota dichotoma which produces diterpenes that have deterrent action against sympatric fishes (HAY et al., 1987).

Crabs belonging to the family Epialtidae (Brachyura: Oxyrhyncha) are mainly herbivores and are commonly referred to as spider crabs. Some of them are also known to decorate themselves with pieces of seaweed and sessile invertebrates. This behavior provides them with camouflage and is also a defensive strategy against predators (WICKSTEN, 1993; STACHOWICZ; HAY 1999; STACHOWICZ; HAY, 2000). In general, this behavior is understood as selective, because the decoration can use seaweeds that are relatively rare but are unpalatable to fishes (STACHOWICZ; HAY, 1999; STACHOWICZ; HAY, 2000), and the camouflage can be more important than the food (WOODS; MCLAY 1994).

Analogously to small herbivores that live in association with chemically defended seaweeds, crabs that mask themselves with chemically defended algae ought to be better protected against predators. Field assays have demonstrated that individuals of the crab genus Libinia forced to decorate themselves with the non-defended seaweed Hypnea sp. were more consumed by omnivorous fishes than individuals decorated with Dictyota menstrualis, a seaweed known to produce the dictyol $\mathrm{E}$ diterpene that acts as a deterrent against sympatric fishes (STACHOWICZ; HAY, 1999). Likewise, the crab Macropodia rostrata decorates itself almost exclusively with Dictyota linearis, which produces diterpenes similar to those produced by D. menstrualis (CRUZ-RIVERA 2001); even in the absence of experimental proof, it is reasonable to think that $M$. rostrata also gains protection through this interaction.

Another hypothesis suggests that decorating behavior can be related to food storage. During periods of intense predator activity, masked crabs display less activity and keep hidden. These crabs also consume the seaweeds used for decorating as food items during such periods (KILAR; LOU, 1986; WOODS; MCLAY, 1994).
The decorator crab Acanthonyx scutiformis (Dana, 1851) is endemic to the Brazilian coast and ranges from Espírito Santo to São Paulo states. At Praia Rasa (Rio de Janeiro State), A. scutiformis can be found mainly associated with mats of Plocamium brasiliense, a red seaweed known to produce defensive chemicals against herbivores. However, despite its distribution and abundance, little is known about the biology and ecology of A. scutiformis. The present paper thus aims to address the following questions: 1 . Is $P$. brasiliense the seaweed most consumed by $A$. scutiformis at Praia Rasa? 2. Is the feeding preference of A. scutiformis related to the occurrence of chemicals in seaweeds? 3. Is decorating behavior related to the feeding preference of this crab?

\section{Material and Methods}

Study Site and Organisms

Seaweed and crab collection was performed at Praia Rasa (22 $44^{\prime}$ 'S; $\left.41^{\circ} 57 \mathrm{~W}\right)$, located in Armação dos Búzios, on the northern coast of Rio de Janeiro State. These organisms were collected in the sublittoral zone at spring ebb tide by snorkeling. Four seaweed species common in that region were chosen to assess the feeding preference of the crab Acanthonyx scutiformis (Dana, 1851): the red species Plocamium brasiliense and Osmundaria obtusiloba, and the brown species Dictyota menstrualis and Sargassum sp. As A. scutiformis is closely associated with $P$. brasiliense, the crabs were assessed by the collection of this seaweed. After collection, the crabs were transported to the laboratory, where each piece of seaweed used by the crabs as decoration was carefully removed before they were placed in an aquarium with seawater and kept in individual perforated plastic vials. The collected seaweeds were separated into two portions. One portion was kept fresh and used to assess the crab's feeding preference, while the other was air-dried in the shade in order to avoid photolysis and thermal degradation of the metabolites, and then submitted to exhaustive extraction with dichloromethane. This procedure has been used and it preserved the chemical characteristics of the seaweed species that could act as defense against consumers (PEREIRA et al., 2000a, b).

\section{Feeding Preference - Fresh Seaweeds}

Before the experiment began the crabs were fed on a diet based on Ulva spp., since starvation can alter the feeding preference of some herbivores (see Cronin; Hay, 1996). In order to assess the feeding preference of the crab A. scutiformis, a feeding 
preference bioassay was conducted with fresh seaweeds, which consisted of a multiple-choice assay. In this assay four food items ( $P$. brasiliense, $O$. obtusiloba, D. menstrualis and Sargassum sp.) were offered simultaneously to one individual of $A$. scutiformis in each plastic vial $(\mathrm{n}=20)$. Each seaweed was cut into small pieces of similar volume which were wet-weighed with a salad spinner after removal of excess water. As a control, 20 replicates in the same conditions were used but without the crab, in order to verify possible autogenetic variations. After 72 hours the assay was interrupted and the seaweed pieces weighed once again, after removal of excess water.

\section{Feeding Preference - Crude Extracts}

The four dried seaweeds ( $P$. brasiliense, $O$. obtusiloba, D. menstrualis and Sargassum sp.) were submitted to exhaustive extraction (45 days) using dichloromethane, which provided corresponding crude extracts. After filtration, the extracts were concentrated and incorporated into artificial food wafers (described in Hay et al., 1994) prepared with powdered Ulva sp. Treated artificial food wafers were prepared by adding $0.72 \mathrm{~g}$ of agar to $20.0 \mathrm{ml}$ of distilled water and heated to a boil in a microwave oven. This mixture was then added to $16.0 \mathrm{ml}$ of distilled water containing $2.0 \mathrm{~g}$ of each freeze-dried Ulva containing the crude extract. A total of $2.0 \mathrm{~g}$ of each alga was used to obtain the corresponding extract in order to reproduce the natural concentration of chemicals of the seaweeds assayed (volumetric basis). The mixture of each extract of the four species was hardened onto a mesh screen and cut into small pieces (10.0 x $10.0 \mathrm{~mm}$ squares). Control food wafers were prepared in the same way, but without the crude extract. In each assay, control and treatment mesh screens of each species were then simultaneously and equidistantly offered to the crab in each container $(n=$ 20). Feeding preference was assessed by comparing the percentage of squares of treated and control food wafers consumed.

\section{Decorating Behavior}

The occurrence of decorating behavior in $A$. scutiformis was first evaluated in the field through observation of the crabs collected $(n=23)$. The seaweed species used as a mask by the crabs and their frequency were recorded before they were brought to the laboratory. The crabs used in the fresh seaweed assay were carefully observed at the end of the experiment $(n=9)$. Once again, the number of pieces of each seaweed used in the decorating behavior was recorded to assess the frequency with which each item was used.

\section{Statistical Analysis}

The feeding preference bioassays were analyzed through the average percentage consumption of each seaweed or artificial food. A $t$-test for independent samples between the mass consumed by the crab and the autogenetic variation was used to verify whether the mass found in the fresh seaweed assay could be attributed to the crab's consumption. A significant $p$-value $(p<0.05)$ indicates that the mass variation can be attributed to consumption, while a non-significant $p$-value $(p>0.05)$ indicates that it can be attributed to autogenetic variation.

\section{Results}

Feeding Preference - Fresh Seaweeds

The analysis of the data obtained from the feeding preference assay with fresh seaweeds and the data obtained from the autogenetic variation for the four species (P. brasiliense, $O$. obtusiloba, $D$. menstrualis and Sargassum sp.) were statistically significant $(p<0.05)$. Mass variation can then be attributed to consumption by the crab, and only the consumption percentage for each of the four species is shown in Figure 1. Although all four seaweeds were consumed, $O$. obtusiloba was evidently the species most consumed $(35.33 \%)$ and D. menstrualis, the least $(12.0 \%)$.

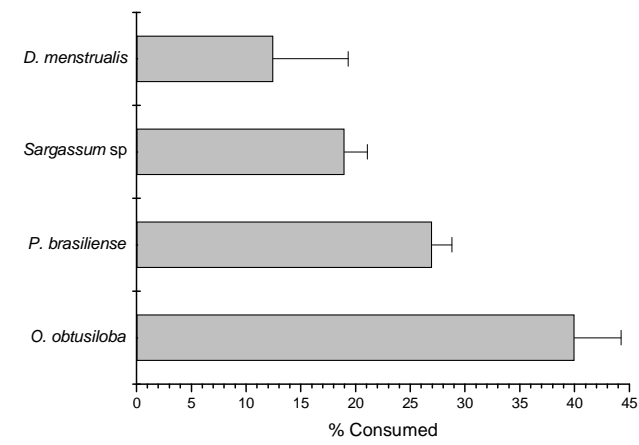

Fig. 1. Feeding preferences of the crab Acanthonyx scutiformis for live seaweeds in a multiple choice laboratory assay. The losses of biomass due to herbivory and autogenic changes are compared ( $t$ test, $\alpha=0.05$ ). Horizontal bars at each point represent mean and standard deviations. $\mathrm{N}=20$.

\section{Feeding Preference - Crude Extracts}

The consumption percentage for each artificial food is shown in Figure 2. The same pattern as that of the fresh seaweed assays was also obtained with the artificial food. The food containing $O$. obtusiloba extract was the most consumed (27.0\%), and that with the $D$. menstrualis extract the least consumed $(1.5 \%)$. 


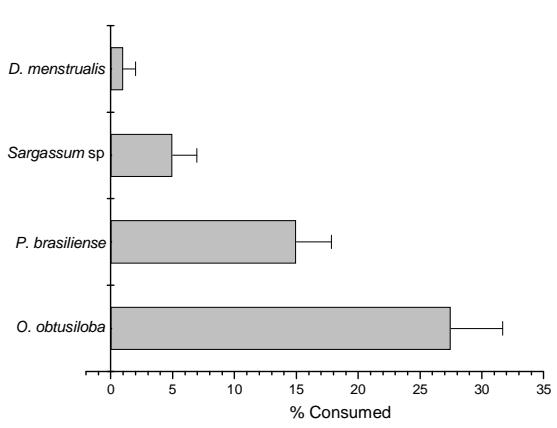

Fig. 2. Effect of crude extracts from seaweeds on the consumption of the crab Acanthonyx scutiformis in multiplechoice laboratory assay. Horizontal bars at each point represent mean and standard deviations. $\mathrm{N}=20$.

\section{Decorating Behavior}

In the field, A. scutiformis was found preferentially with $P$. brasiliense (18 of 23) followed by $D$. menstrualis ( 5 of 23 ), Figure $3 \mathrm{~A}$. Small pieces of $P$. brasiliense were observed attached to the crabs collected in the field.

Decorating behavior was also observed after the fresh seaweed bioassay in only nine individuals that had small pieces of seaweed attached to the rostrum. Of these nine, six were decorated with pieces of $P$. brasiliense and three with $D$. menstrualis (Fig. 3B).

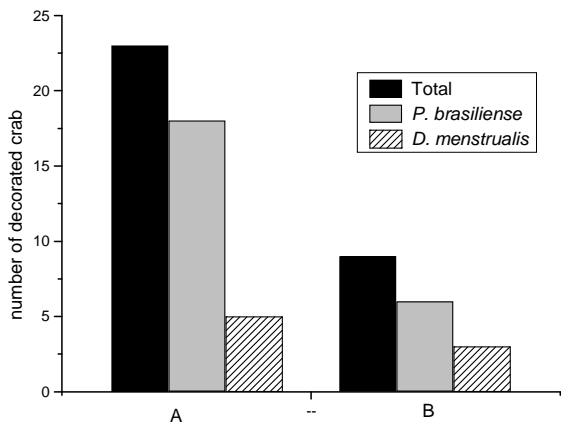

Fig. 3. Preferences in decoration by Acanthonyx scutiformis found in: A. field sample, and B. a multiple-choice laboratory assay.

\section{Discussion}

The results presented in this paper suggest that although $A$. scutiformis feeds preferentially on $O$. obtusiloba and $P$. brasiliense, this crab exhibits a generalist feeding pattern as regards the seaweed assayed. This feeding behavior may be interpreted as a local strategy, since the benthic community at Praia Rasa undergoes great changes in the dominance of seaweeds along the year (YONESHIGUE;
VALENTIN, 1988; YONESHIGUE-VALENTIN; VALENTIN, 1992; GUIMARAENS; COUTINHO, 1996). Despite this seasonal variation, O. obtusiloba seems to be a perennial and highly abundant species, being available to herbivore populations in general, and also to A. scutiformis specifically, throughout the year. On the other hand, during the fall and winter months $P$. brasiliense and $D$. menstrualis cannot be seen in the Praia Rasa community. Thus, the perennial presence of $O$. obtusiloba can help explain the evident feeding preference of A. scutiformis for this red seaweed.

Feeding behavior in other epialtid crabs seems to be related to the species and to the occurrence of seaweeds. Species of Libinia exhibit generalist behavior, feeding on a large variety of seaweed species (STACHOWICZ; HAY, 1999), as do other species of Acanthonyx (CRUZ-RIVERA, 2001). By contrast, other Epialtidae species seem to present a very specialized feeding pattern (STACHOWICZ; HAY, 1996).

Based on these results it may be presumed that the association between the crab A. scutiformis and the alga $P$. brasiliense is related to a factor other than the consumption of the alga by the crab. Plocamium brasiliense is a highly branched seaweed and at Praia Rasa it grows in dense mats. This complex structure, associated with its occurrence in high densities, makes it an efficient shelter against predators for A. scutiformis. In addition, many studies have shown that several species of the genus Plocamium produce monoterpenes which potentially mediate an array of chemical interactions as defense against herbivores (SAKATA et al., 1991; ANKSETTY et al., 2004), epibiosis (KONIG et al., 1999) and against competitors (DE NYS et al., 1991). Therefore, the association with $P$. brasiliense grants the crab an even safer shelter against generalist predators like omnivorous fishes, since this seaweed seems to contain chemical compounds that deter feeding by those predators. The hypothesis that $A$. scutiformis lives preferentially associated with $P$. brasiliense during the months in which this seaweed is abundant and possibly feeds on $O$. obtusiloba during periods when predators are less active remains to be tested.

Despite the ubiquity of camouflage as a predator defense strategy, for marine crabs as well, this aspect has been very little explored by field evaluation, but decoration camouflage has reduced predation on the epialtidae Pugettia richii in laboratory assays (HULTGREN; STACHOWICZ, 2008). On the other hand, the importance of the decorating behavior of the juvenile of the crab Pugettia producta is probably related to feeding rather than to the protection offered by the algal camouflage (MASTRO, 1981). 
We have not tested these hypotheses for $A$. scutiformis, but considering our field and laboratory results, it is possible to draw some inferences. The collected crabs were immediately examined and some of them showed small pieces of $P$. brasiliense attached to the rostrum. After the feeding preference bioassay with fresh seaweeds, a similar trend was observed, with only some crabs decorated with small pieces of the chemically defended $P$. brasiliense or $D$. menstrualis. A similar pattern of attaching small pieces of algae has been observed in other species of Acanthonyx, as well as in other Epialtidae (Wicksten 1993). For example, not all individuals of Acanthonyx lunulatus attached algae to their rostrums, but all those that did used small pieces of Jania rubens exclusively (CRUZ-RIVERA, 2001).

A color-mediated crypsis strategy such as color change by sequestering diet-derived pigments has also been suggested as another camouflage strategy against predation in crabs (HAY et al., 1990; WOODS; MCLAY, 1996). Acanthonyx petiveri attached small algae to the rostrum (WILSON, 1987), but body color provided some crypsis regardless of coloration, and different color morphs of $A$. petiveri tended to associate selectively with algae of similar color. Similarly, A. lunulatus individuals from the Mediterranean coast commonly exhibit a brown color (although green individuals can also be found) and are frequently found associated with brown seaweeds (CRUZ-RIVERA, 2001). Color camouflage primarily reduces predation on Pugettia producta, but this crab changed color only when molting (HULTGREEN; STACHOWICZ, 2008). Individuals of A. scutiformis that lived in association with $P$. brasiliense mats exhibited a dark red color in the field. However, when kept in the laboratory eating fresh Ulva spp. before the start of the assays, their color rapidly changed to green in a period of no more than one week, from the center to the periphery of the caparace, but only on the body or live tissue of the crab, not on the carapace itself. This fact supports a supposed color-mediated crypsis in the crab studied, but rather than selecting seaweeds of similar color, A. scutiformis seems to change its own color according to the pigments of the algae eaten.

No association between the feeding and decorating preference of $A$. scutiformis for seaweeds was observed. Whereas in both fresh seaweeds and crude extract assays A. scutiformis consumed preferentially $O$. obtusiloba, and to a lesser extent $P$. brasiliense, the alga preferentially used as decoration in crabs observed both after collection and after the assays was $P$. brasiliense. An absence of any association between feeding and decorating preferences (SATO; WADA, 2000; CRUZ-RIVERA, 2001) and the utilization of small pieces of seaweed as decoration (CRUZ-RIVERA, 2001) argues against this behavior as an effective strategy for food storage.

The algae used by $A$. scutiformis as decoration ( $P$. brasiliense and D. menstrualis) present a finely branched morphology and a very thin structure as compared to those of $O$. obtusiloba and Sargassum sp. According to Cruz-Rivera (2001), algal morphology is capable of influencing the selection of decoration materials. Decorator crabs attach algae to hook-like setae present all along their bodies (WOODS; MCLAY, 1994) and appear to decorate themselves more readily with thinner algae, which are presumably easier to cut and attach to the setae (STACHOWICZ; HAY 1999; STACHOWICZ; HAY 2000).

This paper presents evidence that the majid crab A. scutiformis is a generalist feeder, although some preference for $O$. obtusiloba and $P$. brasiliense could be observed. Moreover A. scutiformis lives in association with the chemically-defended $P$. brasiliense and uses this alga as preferential decoration, which supposedly entails an even more effective deterrence against generalist predators. This association seems to be very restricted, since crabs have been observed only within $P$. brasiliense mats and the crab's fate during the months when this alga is absent is uncertain. Besides, the effectiveness of the decoration protection and the degree to which $A$. scutiformis utilizes $P$. brasiliense chemicals as antipredator deterrents are as yet unknown, and must be the object of future research.

\section{ACKNOWLEDGEMENTS}

This work was supported by the Conselho Nacional de Desenvolvimento Científico e Tecnológico (CNPq) and the Fundação de Amparo à Pesquisa do Estado do Rio de Janeiro (FAPERJ), through research grants.

\section{REFERENCES}

ANKISETTY, S.; NANDIRAJU, S.; WIN, H.; PARK, Y. C.; AMSLER, C. D.; MCCLINTON, J. B.; BAKER, J. A.; DIYALABANAGE, T. K.; PASARIBU, A.; SINGH, M. P.; MAIESE, W. M.; WALSH, R. D., ZAWOROTKO, M. J.; BAKER, B. J. Chemical investigation of predatordeterred macroalgae from the Antarctic Peninsula. J. nat. Prod., v. 67, p. 1295-1302, 2004.

BARRY, J.; EHRET, M. Diet, food preference, and algal availability for fishes and crabs on intertidal reef communities in southern California. Environ. Biol. Fishes, v. 37, p. 75-95, 1993.

CRONIN, G.; HAY, M. E. Susceptibility to herbivores depends on recent history of both plant and the animal. Ecology, v. 77, p. 1531-1543, 1996. 
CRUZ-RIVERA, E. Generality and specificity in the feeding and decoration preferences of three Mediterranean crabs. J. exp. mar. Biol. Ecol., v. 266, p. 17-31, 2001.

DE NYS R.; COLL, J. C.; PRICE, I. R. Chemically mediated interactions between the red alga Plocamium hamatum (Rhodophyta) and the octocoral Sinularia cruciata (Alcyonacea). Mar. Biol., v. 108, p. 115-320, 1991.

DUFFY, J. E.; HAY, M. E. Food and shelter as determinants of food choice by an herbivorous marine amphipod. Ecology, v. 72, p. 1286-1298, 1991.

GRANADO, I.; CABALLERO, P. Feeding rates of Littorina striata and Osilinus atratus in relation to nutritional quality and chemical defenses of seaweeds. Mar. Biol., v. 138, p. :1213-1224, 2001.

GUIMARAENS, M. A.; COUTINHO, R. Spatial and temporal variation of benthic marine algae at the Cabo Frio upwelling region, Rio de Janeiro, Brazil. Aquat. Bot., v. 52, p. 283-299, 1996.

HAY, M. E. The role of seaweeds chemical defense in the evolution of feeding specialization and in the mediation of complex interactions. In: PAUL V. J. (Ed.). Ecological roles of marine natural products. New York: Cornell University Press, 1992. p. 93-118.

HAY, M. E. Marine chemical ecology: what's known and what's next? J. exp. mar. Biol. Ecol., v. 200, p. 103-134, 1996.

HAY, M. E.; DUFFY, J. E.; PFISTER, C. A.; FENICAL, W. Chemical defense against different marine herbivores: are amphipods insect equivalents? Ecology, v. 68, p. 1567-1580, 1987.

HAY, M. E.; DUFFY, J. E.; PAUL, V. J.; RENAUD, P. E.; FENICAL, W. Specialist herbivores reduce their susceptibility to predation by feeding on the chemically defended seaweed Avrainvillea longicaulis. Limnol. Oceanogr., v. 35, p. 1734-1743, 1990.

HAY, M. E.; KAPPEL, Q. E.; FENICAL, W. Synergism in plant defenses against herbivores: interactions of chemistry, calcification, and plant quality. Ecology, v. 75, p. 1714-1726, 1994.

HULTGREN, K. M.; STACHOWICZ, J. J. Alternative camouflage strategies mediate predation risk among closely related co-occurring kelp crabs. Oecologia, v. 155 , p. $519-528,2008$.

KILAR, J.; LOU, R. The subtleties of camouflage and dietary preference of the decorator crab, Microphrys bicornutus Latreille (Decapoda: Brachyura). J. exp. mar. Biol. Ecol., v. 101, p. 143-160, 1986.

KONIG, G. M.; WRIGHT, A. D.; DE NYS, R. Halogenated monoterpenes from Plocamium costatum and their biological activity. J. nat. Prod., v. 62, p. 383-385, 1999.

MASTRO, E. Algal preferences for decoration by the Californian kelp crab, Pugettia producta (Randall) (Decapoda, Majidae). Crustaceana, v. 41, p. 64-70, 1981.

MCSHANE, P. E.; GORFINE, H. K.; KNUCKEY, I. A Factors influencing food selection in the abalone Haliotis rubra (Mollusca, Gastropoda). J. exp. mar. Biol. Ecol. v. 176, p. 27-37, 1994.

NEIGHBORS, M. A.; HORN, M. H. Nutritional quality of macrophytes eaten and not eaten by two temperate zone herbivorous fishes: A multivariate comparison. Mar Biol., v. 108, p. 471-476, 1991.
PAUL, V. J.; PUGLISI, M. P. Chemical mediation of interactions among marine organisms. Nat. Prod. Rep., v. 21, p. 189-209, 2004.

PAUL, V. J.; CRUZ-RIVERA, E.; THACKER, R. W. Chemical mediation of macroalgal-herbivore interactions: ecological and evolutionary perspectives. In: MCCLINTOCK, J. B.; Baker, B. J. (Ed.) Marine Chemical Ecology. Boca Raton, FLA: CRC Press, 2001. p. 227-265.

PAUL, V. J.; PUGLISI, M. P.; RITSON-WILLIAMS, R. Marine chemical ecology. Nat. Prod. Rep., v. 23, p. 153-180, 2006

PEREIRA, R. C.; CAVALCANTI, D. N.; TEIXEIRA, V. L. Effects of secondary metabolites from the tropical Brazilian brown alga Dictyota menstrualis on the amphipod Parhyale hawaiensis. Mar. Ecol. Prog. Ser., v.205, p. 95-100, 2000a..

PEREIRA, R. C.; DONATO, R.; TEIXEIRA, V. L.; CAVALCANTI, D. N. Chemotaxis and chemical defenses in seaweed susceptibility to herbivory. Rev. Bras. Biol., v. 60, p. 405-414, 2000 b.

SAKATA, K.; IWASE, Y.; INA, K.; FUJITA, D. Chemical studies on feeding inhibitors for marine herbivores. 2. Halogenated terpenes isolated from the red alga Plocamium leptophyllum as feeding inhibitors for marine herbivores. Nipp. Suisan Gakk., v. 57, p. 743-746, 1991

SATO, M.; WADA, K. Resource utilization for decorating in three intertidal majid crabs (Brachyura: Majidae). Mar. Biol., v. 137, p. 705-714. 2000.

STACHOWICZ, J. J.; HAY, M. E. Facultative mutualism between an herbivorous crab and a coralline alga: advantages of eating noxious seaweeds. Oecologia, v. 105 , p. 377-387, 1996.

STACHOWICZ, J. J.; HAY, M. E. Reducing predation through chemically mediated camouflage: indirect effects of plant defenses on herbivores. Ecology, v. 80, p. 495-509, 1999.

STACHOWICZ, J. J.; HAY, M. E. Geographic variation in camouflage specialization by a decorator crab. Am. Naturalist., v. 156, p. 59-71, 2000.

VADAS, R. L. Preferential feeding: an optimization strategy in sea urchins. Ecol. Monogr., v. 47, p. 337-371, 1977.

WICKSTEN, M. Decorating crabs. Sci. Am., v. 242, p. 146154, 1980.

WICKSTEN, M. A review and a model of decorating behavior in spider crabs (Decapoda, Brachyura, Majidae). Crustaceana, v. 64, p. 314-325, 1993.

WILSON, R. Substrate selection and decorating behavior in Acanthonyx petiveri related to exoskeleton color (Brachyura, Majidae). Crustaceana, 52:135-140, 1987.

WOODS, C. M. C.; MCLAY, C. L. Use of camouflage materials as a food store by the spider crab Notomithrax ursus (Brachyura: Majidae). New Zeal. J. mar. fresh. Res. v. 28, p. 97-104, 1994.

WOODS, C. M. C.; MCLAY, C. L. Diet and cryptic coloration of the crab Eurynolambrus australis (Brachyura: Majidae) at Kaikoura. Crust. Res., v. 25, p. 32-43, 1996.

YONESHIGUE Y.; VALENTIN, J. L. Comunidades algais fotófilas de infralitoral de Cabo Frio, Rio de Janeiro, Brasil. Gayana Bot., v. 45, p. 61-75, 1988. 
YONESHIGUE-VALENTIN, Y.; VALENTIN, J. L.

Macroalgae of the Cabo Frio upwelling region, Brazil: ordination of communities. In: SEELIGER, R. (Ed.).

Coastal plants of Latin America. San Diego, CA: Academic Press, 1992. p. 31-49.

(Manuscript received 20 December 2008; revised 31 March 2008; accepted 03 September 2008) 